\title{
Pemberdayaan Kelompok Koperasi Wanita Putri Jati Emas Melalui Pembuatan Houseware dari Limbah Vinil
}

\section{The Empowerment of Women's Cooperative Group Putri Jati Emas Through Houseware Making Made of Vinyl Waste}

\author{
${ }^{1}$ Agita Risma Nurhikmawati, ${ }^{2}$ Wachidatul Linda Yuhanna \\ ${ }^{1}$ Jurusan Pendidikan Bahasa Inggris, Fakultas Keguruan dan Ilmu pendidikan, Universitas \\ PGRI Madiun, Madiun \\ ${ }^{1}$ Jurusan Pendidikan Biologi, Fakultas Keguruan dan Ilmu pendidikan, Universitas PGRI \\ Madiun, Madiun
}

Korespondensi: W.L. Yuhanna, linda.yuhanna.wiguno@gmail.com

\begin{abstract}
Naskah Diterima: 3 September 2019. Disetujui: 22 Juni 2020. Disetujui Publikasi: 25 Juni 2020
\end{abstract}
\begin{abstract}
Vinyl waste is synthetic waste that is difficult to decompose. In Setono, there are 2 car upholstery and 1 shoe making industries which produce approximately $10 \mathrm{~kg}$ of vinyl waste per day. Thus, this study conducts vinyl waste processing by involving women's cooperative group, Putri Jati Emas. Vinyl waste is chosen since it can be made into high-selling houseware. The method in this activity is waste sorting, product designing, pattern making, printing, pattern cutting, sewing, sticking vinyl to houseware, and product finishing. In general, this activity went well and was conducive. In addition, the community is very enthusiastic and active in participating the program. In consequences, the participants' skill level increases up to $80 \%$. The houseware produced are trash bins, tissue containers, snack jars, biscuit tins, trays, and flower pots. In conclusion, this program is very relevant for improving the skills of the women in supporting family income.
\end{abstract}

Keywords: Houseware, waste, vinyl.

\begin{abstract}
Abstrak. Limbah vinil merupakan limbah sintetis yang sulit terurai dan tidak dimanfaatkan. Di Desa Setono terdapat 2 industri jok mobil dan 1 industri pembuatan sepatu yang menghasilkan limbah vinil sebanyak $10 \mathrm{~kg}$ per hari. Pengolahan limbah vinil dilakukan dengan melibatkan kelompok koperasi wanita Putri Jati Emas. Limbah vinil dapat dikreasikan menjadi produk houseware berdaya jual tinggi. Metode dalam kegiatan ini adalah sortasi limbah, pemaparan desain, pembuatan pola, mencetak, menggunting pola, menjahit, menempel pada produk houseware dan finishing produk. Secara umum kegiatan ini berjalan lancar dan kondusif. Masyarakat antusias dalam mengikuti pelatihan. Tingkat keterampilan masyarakat sasaran sebanyak $80 \%$. Produk yang dihasilkan berupa tempat sampah, tempat tissue, toples, kreasi kaleng biskuit, nampan dan pot bunga. Pelatihan kreasi limbah vinil menjadi houseware sangat relevan dan bermanfaat bagi peningkatan skill kelompok Koperasi Wanita Putri Jati Emas.
\end{abstract}

Kata Kunci: Houseware, limbah, vinil,

\section{Pendahuluan}

Bahan vinil merupakan bahan sintetis dari serat polyester yang sulit untuk diuraikan oleh tanah dan bakteri. Bahan vinil digunakan pada industri jok mobil, springbed, kursi sofa dan industri sejenis lainnya (Pujiati, 2015). Limbah potongan kain vinil banyak dihasilkan dan belum termanfaatkan sepenuhnya. Limbah vinil 
kebanyakan hanya dibuang di sungai dan di bakar, yang mengakibatkan pencemaran lingkungan yang berbahaya. Di satu sisi limbah vinil masih dapat digunakan menjadi produk yang mempunyai daya jual.

Desa Setono merupakan salah satu desa di Kecamatan Ngrambe, Kabupaten Ngawi Jawa Timur yang terdapat 2 UMKM jasa interior mobil dan 1 industri sepatu. UMKM tersebut setiap harinya menghasilkan limbah berupa kain perca vinil sebanyak 10 kilogram. Limbah vinil hanya dibiarkan dan dibakar. Limbah vinil ini tidak dapat terurai dengan mudah sehingga memerlukan penanganan berbasis reuse dan recycle (Usaid, 2015; Karno, 2013).

Salah satu inovasi untuk meningkatkan nilai guna dan nilai jual limbah vinil adalah menggunakannya sebagai bahan houseware. Houseware adalah peralatan rumah tangga yang sering digunakan seperti toples, piring, nampan, tempat tissue, gelas dan beraneka peralatan lainnya (Indahyani, 2016). Penggunaan limbah vinil dapat dikolaborasikan dengan houseware yang dikemas secara kreatif dan menarik. Herlambang (2018) menyatakan bahwa kreativitas adalah kunci utama dalam pengembangan industri kreatif. Produk houseware dengan menggunakan kreasi bahan vinil mempunyai nilai jual yang tinggi dan dapat mengurangi limbah.

Upaya mendaur ulang limbah vinil menjadi produk houseware dilakukan dengan melibatkan kelompok masyarakat Desa Setono. Sinergisitas antara kelompok masyarakat produktif menjadi komponen vital dalam menyelesaikan permasalahan di masyarakat (Adriansyah et.al, 2017). Organisasi masyarakat yang menjadi target adalah kelompok Koperasi Wanita Putri Jati Emas. Secara umum kegiatan keorganisasian kelompok ini berjalan lancar. Ketua dan anggota kelompok Koperasi Wanita mempunyai pemikiran yang komprehensif dalam menjalankan organisasi. Namun saat ini kelompok koperasi wanita Putri Jati Emas, belum ada kegiatan untuk meningkatkan produktivitas dalam usaha meningkatkan pendapat anggota. Kegiatan hanya sebatas rapat rutin, arisan dan simpan pinjam. Pemberdayaan masyarakat sangat diperlukan sebagai upaya meiningkatkan skill dan pendapatan ibu-ibu berbasis ekonomi kreatif.

Pembuatan houseware dari limbah vinil ini merupakan salah satu bentuk pemberdayaan masyarakat yang mempunyai tujuan positif. Pemberdayaan kelompok Koperasi Wanita Putri Jati Emas ini dilakukan secara kolaboratif. Vinda (2017) dan Saidah (2017) menjelaskan bahwa pemberdayaan masyarakat merupakan salah satu upaya dalam meningkatkan taraf hidup masyarakat menuju kemandirian ekonomi dan sosial. Pemberdayaan masyarakat bersifat people centered dengan pendekatan partisipatif agar memudahkan penyampaian pengetahuan (Suryolaksono, 2015). Pemberdayaan masyarakat khususnya perempuan, sangat potensial dilakukan untuk membangun keluarga yang mandiri dan produktif dengan memanfaatkan skill yang ada (Rochaya, 2011).

Tujuan dari kegiatan pengabdian masyarakat ini adalah untuk memanfaatkan limbah vinil menjadi produk houseware dan meningkatkan keterampilan kelompok Koperasi Wanita Putri Jati Emas melaui pembuatan limbah vinil menjadi houseware.

\section{Metode Pelaksanaan}

Tempat dan Waktu. Kegiatan ini dilakukan di Desa Setono Kecamatan Ngrambe Kabupaten Ngawi Jawa Timur pada bulan Juli tahun 2019.

Khalayak Sasaran. Khalayak sasaran terdiri dari anggota Koperasi Wanita Putri Jati Emas sejumlah 30 orang.

Metode Pengabdian. Alat yang digunakan yaitu mesin jahit, gunting, pulpen, penggaris, dan cutter. Bahan yang digunakan yaitu houseware, limbah vinil, lem, karton, benang kaleng bekas dan hiasan. Kegiatan Pengabdian masyarakat terdiri dari 2 kegiatan yaitu:

1) Penyuluhan pemanfaatan limbah vinil 
Penyuluhan pemanfaatan limbah vinil dilakukan dengan memberikan materi tentang limbah vinil, industri kreatif, dan tata cara pembuatan houseware.

2) Praktik pembuatan Houseware dari Limbah Vinil

a. Sortasi limbah vinil. Limbah vinil berasal dari industri jok dan interior mobil dipilih sesuai dengan warna, ukuran dan jenis bahan. Sortasi bertujuan untuk memudahkan peserta untuk memadukan warna dan bentuk sesuai pola.

b. Pemaparan desain. Pemaparan desain oleh tim pengabdian masyarakat sebanyak 7 desain.

c. Pembuatan pola. Pembuatan pola disesuaikan dengan houseware yang akan dihias dengan bahan vinil. Pola dilakukan pada kertas karton.

d. Mencetak dan menggunting pola. Pola yang sudah jadi dicetak pada limbah vinil dan digunting sesuai dengan bentuk dan ukuran yang telah dipilih.

e. Menjahit dan menempel sesuai dengan model. Menjahit kain vinil sesuai pola, kemudian ditempelkan pada houseware yang akan dihias.

f. Finishing produk. Produk houseware yang telah dikreasikan dengan bahan limbah vinil dirapikan dan dikemas secara menarik.

Indikator Keberhasilan. Indikator keberhasilan program ini 1) Peningkatan pemahaman peserta (baik dan sangat baik di atas $75 \%$ ) yang didapat dari materi yang telah diberikan ketika penyuluhan. 2) Adanya 5 produk baru hasil kreasi houseware dari limbah vinil setelah melakukan praktik pembuatan houseware dari limbah vinil.

Metode Evaluasi. Metode evaluasi yang digunakan untuk mengukur ketercapaian pemahaman peserta dari penyuluhan (Setyaningrum \& Hartanto, 2020) adalah 1) Menyebarkan angket pemahaman yang berisi sejumlah 10 pernyataan terkait proses pembuatan houseware dari vinyl kepada peserta. 2) Menganalisis angket sesuai dengan kriteria penilaian. Kriteria penilaian pemahaman peserta adalah 010 (kurang baik), 11-20 (cukup baik), 21-30 (baik), 31-40 (sangat baik). Indikator ketercapaian program apabila secara klasikal sebanyak $75 \%$ peserta mempunyai skor 21-40. Sedangkan metode evaluasi untuk mengukur ketercapaian praktik pembuatan houseware dari limbah vinil melakukan unjuk kerja pembuatan produk houseware sebanyak minimal 5 produk.

\section{A. Penyuluhan Pemanfaatan Limbah Vinil}

Kegiatan pengabdian masyarakat berupa pelatihan pembuatan houseware dari limbah vinil ini secara umum berjalan lancar dan kondusif. Kelompok Koperasi Wanita Putri Jati Emas sangat antusias dalam memanfaatkan limbah vinil menjadi houseware. Selama 3 kali pelatihan tingkat kehadiran mencapai 95\%. Kegiatan pembukaan dihadiri oleh Kepala Desa Setono, Ketua Koperasi Wanita Putri Jati Emas, dan Dinas Koperasi dan Usaha Mikro Kabupaten Madiun. Setelah pembukaan dilanjutkan dengan penyampaian materi tentang limbah vinil dan usaha kreatif sebagaimana gambar 1a dan b.

\section{B. Pembuatan Houseware dari Limbah Vinil}

1. Sortasi Limbah Vinil

Sortasi limbah vinil dilakukan untuk memilah bahan vinil yang masih dapat digunakan. Peserta pelatihan pada tahapan ini telah memahami bagian dan jenis kain vinil yang dapat digunakan untuk mengkreasikan produk houseware yang akan dibuat. Limbah yang disortasi sebanyak $100 \mathrm{~kg}$. adanya pemilahan limbah ini sangat membantu peserta dalam menentukan model dan kreasi warna yang akan dibuat. Gambar 2.a.b menunjukkan cara pemilihan limbah vinil berdasarkan ukuran dan warna sehingga cocok untuk dibuat houseware. 

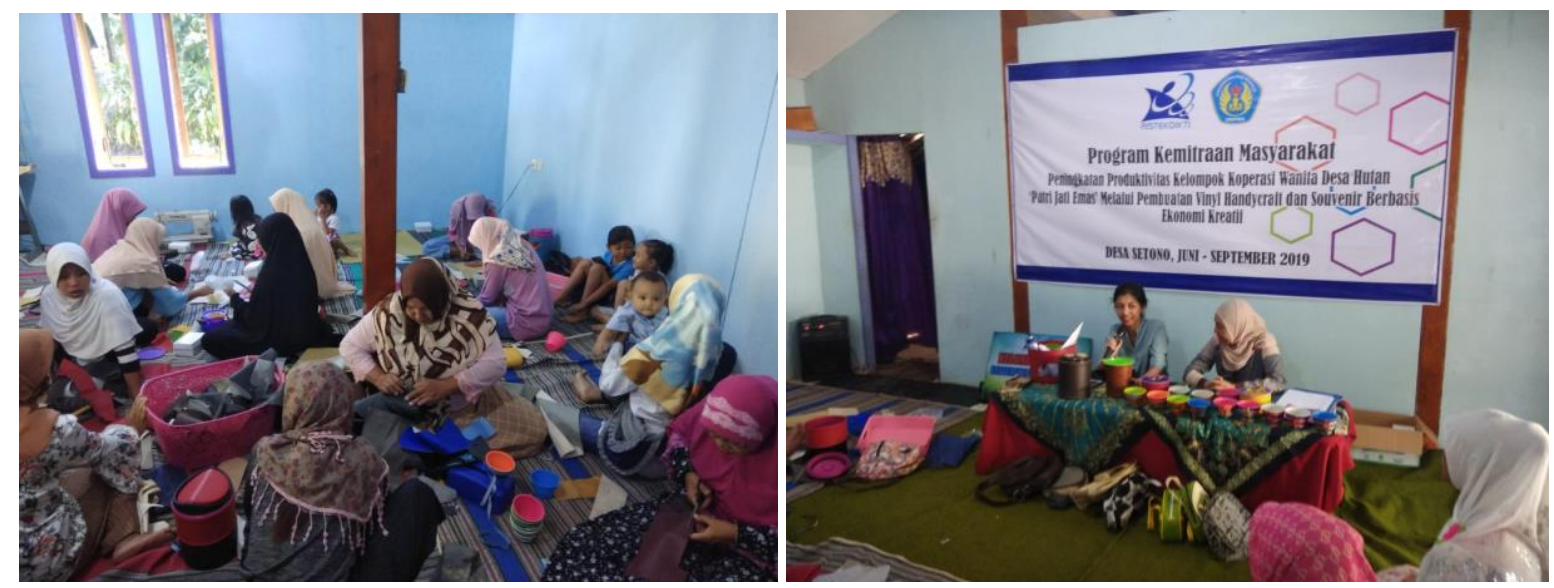

Gambar 1 a,b. Pembukaan dan penyampaian materi awal
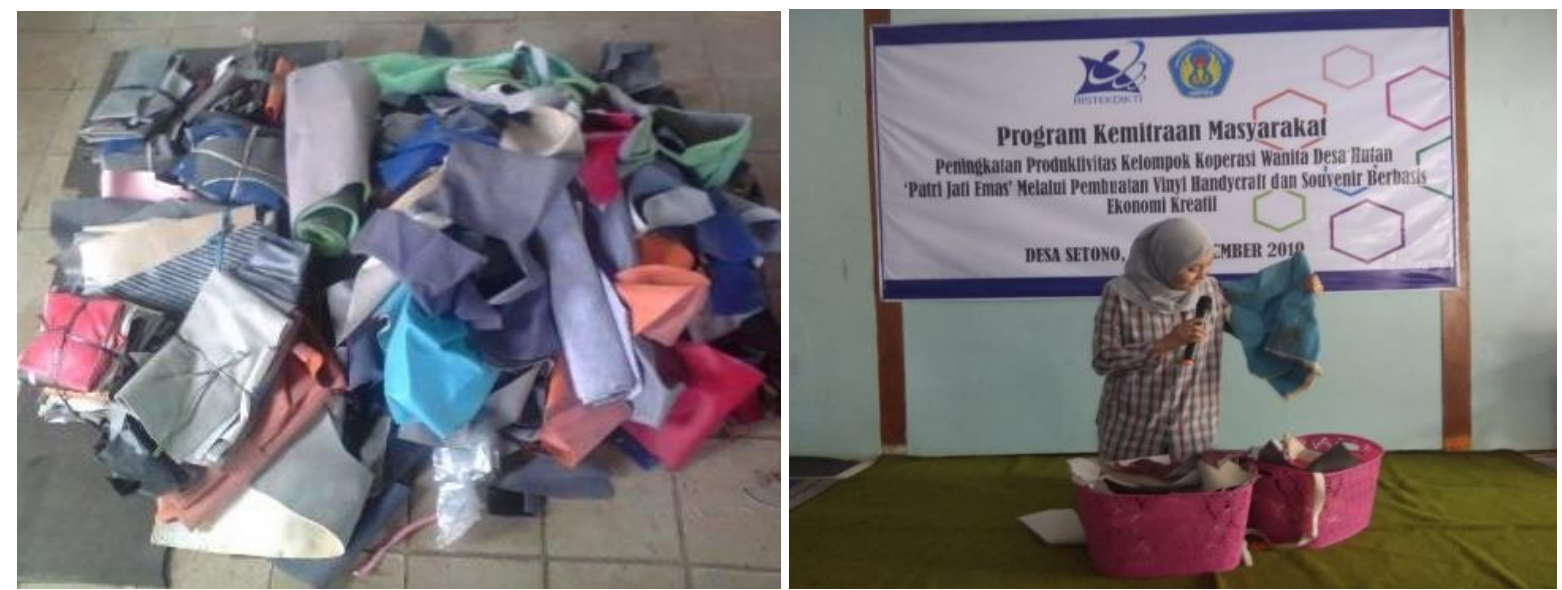

Gambar 2 a,b. Proses Sortasi Limbah Vinil

\section{Pembuatan Desain Houseware Vinil}

Pembuatan houseware dari limbah vinil ini dilakukan mulai dari bentuk sederhana sampai bentuk yang lebih kompeks. Desain yang dilatihkan pada kelompok Koperasi Wanita Putri Jati Emas sebanyak 5 benda yaitu tempat sampah, pot bunga, tempat tissues besar, tempat tissue kecil dan kaleng roti. Proses produksi meliputi pembuatan pola, menggambar pola pada kain vinil, menggunting kain sesuai pola, menjahit bahan vinil dan kemudina merekatkan vinil pada houseware yang akan dibuat.

Pendekatan yang digunakan dalam pengabdian masyarakat ini adalah pendekatan partisipatif dengan melibatkan kelompok masyarakat secara langsung. Pemberian materi secara teoritis sebanyak 30\% dan praktik pembuatan sebanyak $70 \%$. Proporsi praktik yang lebih banyak bertujuan agar masyarakat dapat lebih mudah dalam mengkreasikan produk (Vinda, 2017; Saidah, 2017)

Tahap pertama dalam pembuatan produk adalah pengembangan desain. Proses pengembangan desain dapat diawali dengan adanya inspirasi desain yang dapat diilhami dari alam dan lingkungan di sekitar kita, gambar karakter kartun, dongeng (Indahyani, 2010). Proses pembuatan pola menemui kendala yaitu peserta belum begitu memahami cara membuat proporsi antara pola dasar dan aksesoris. Selain itu peserta masih mengikuti pola dari tim pengabdian masyarakat dan belum mengkreasikan sendiri pola yang akan dibuat. Kendala tersebut dapat diatasi dengan adanya pendampingan secara intensif dan pemaparan model-model dari gambar. Hasan (2018) menyatakan bahwa kreativitas dari peserta harus lebih dibangun, dengan membebaskan peserta mencari ide kreasi dari imajinasinya. 


\section{Pemotongan, Menjahit dan Membuat Houseware Vinil}

Pelatihan hari kedua adalah memotong kain vinil sesuai pola, menjahit dan melekatkan vinil pada produk houseware. Penggunaan mesin jahit modern dapat meningkatkan kualitas produk (Khairani \& Pratiwi, 2018). Pola jahitan yang halus membuat desain yang kita buat semakin menarik dan meningkatkan harga serta quality product. Pelaksanaan proses ini dilakukan dengan berkelompok dengan memilah antara peserta yang bisa menjahit dan yang belum bisa menjahit. Peserta yang mempunyai keahlian menjahit sebanyak 8 orang, dan 22 orang tidak mempunyai keahlian menjahit. Tim pengabdian masyarakat memberikan materi dasar-dasar menjahit bahan vinil, kemudian peserta yang bisa menjahit melakukan penjahitan vinil sesuai pola. Peserta yang tidak bisa menjahit melanjutkan pemotongan pola dan membuat houseware dari vinil tanpa jahitan atau langsung menempel limbah vinil seperti gambar 3a,b,c.

Kendala untuk pelatihan menjahit bahan vinil dan menempel bahan vinil pada houseware adalah 1) Jahitan masih belum rapi karena bahan vinil tergolong bahan yang tebal sehingga membutuhkan skill dan adaptasi terhadap mesin jahit yang digunakan. 2) Bentuk kain yang sudah dijahit belum sesuai dengan ukuran houseware yang akan dihias. 3) Perpaduan warna dalam menjahit bahan belum banyak kreasi. Solusi dari kendala tersebut adalah adanya pendampingan secara intensif dan pemberian contoh produk siap pakai yang dapat ditiru. Pembuatan produk kreasi houseware dari bahan vinil yang tidak dijahit berjalan lancar dan peserta mampu membuat kreasi houseware dari bahan limbah vinil berupa pot dan tepat tissue.
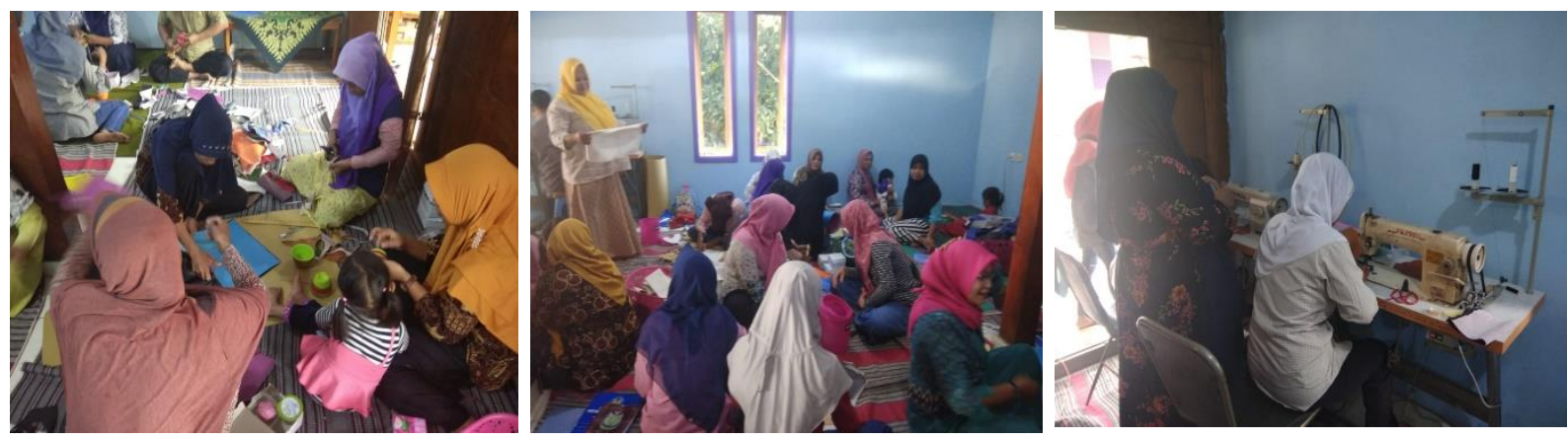

Gambar 3 a,b,c. Pembuatan vinil houseware

\section{Praktik Kreasi Houseware dari Vinil}

Pelatihan hari ketiga diisi praktik langsung pembuatan produk kreasi limbah vinil. Semua peserta bebas mengkreasikan limbah vinil dengan bantuan dan bimbingan dari tim pengabdian masyarakat. Secara umum kegiatan ini juga berjalan lancar. Hasil dari pelatihan ini berupa produk tempat sampah, kotak tissue besar, kotak tissue kecil, kaleng biskuit, pot bunga, nampan dan toples. Berdasarkan angket yang pelaksanaan program, produk yang paling banyak diminati peserta adalah pot bunga vinil (76\%), toples (14\%) dan kaleng biskuit $(10 \%)$.

Produk dari houseware limbah vinil sangat potensial dikembangkan dalam era ekonomi kreatif. Produk houseware diminati masyarakat untuk digunakan sebagai perlengkapan di dalam rumah, hotel, café, kantor dan interior mobil. Adanya inovasi modifikasi dengan menggunakan limbah vinil dapat meingkatkan nilai jual houseware tersebut. Sebagai contoh tempat sampah biasa sebelum dikreasikan dengan limbah vinil hanya dijual Rp. 20.000-, setelah dikreasikan denga limbah vinil harga dapat naik menjadi Rp. 80.000,-. Tempat tissue yang awalnya hanya seharga Rp. 5.000,- dapat meningkat menjadi Rp. 15.000,-. Kaleng bekas biskuit yang tidak terpakai juga dapat dikreasikan dan dijual dengan harga 
Rp. 15.000,-. Potensi bisnis ini dapat dikembangan dan menjadi peluang untuk peningkatan pendapatan ibu-ibu kelompok Koperasi Wanita Putri Jati Emas.

Tim pengabdian kepada masyarakat selain memberikan pelatihan skill berupa kreasi houseware dari limbah vinil, juga memberikan bantuan peralatan berupa mesin jahit, gunting, lem, aksesoris, penggaris dan bahan vinil untuk menjamin keberlanjutan program di kemudian hari. Bantuan ini diserahkan kepada ketua Koperasi Wanita Putri Jati Emas Desa Setono Kecamatan Ngrambe Kabupaten Ngawi. Tim juga berkomitmen untuk terus melakukan pendampingan secara terprogram untuk kegiatan selanjutnya.

\section{Keberhasilan Program Pengabdian Masyarakat}

1. Ketercapaian Pemahaman Materi Houseware dari Limbah Vinil

Pemahaman peserta diukur dengan angket dengan 10 pernyataan Pernyataan meliputi 1) pemahaman limbah vinil, 2) pemahaman industri kreatif, 3) sortasi limbah, 4) membuat pola, 5) memilih perpaduan warna, 6) menggambar pola pada kain vinil, 7) memotong kain limbah vinil, 8) mengelem, 9) menjahit limbah vinil dan 10) finishing produk. Secara umum ketercapaian individu dengan kategori sangat baik (20 orang), baik ( 4 orang), cukup baik (6 orang) dan tidak baik (0 orang). Tingkat keberhasilan individu dinyatakan dengan kriteria sangat baik dan baik sejumlah 24 orang. Presentase keberhasilan secra klasikal sebanyak 80\% berhasil dan $20 \%$ tidak berhasil seperti pada gambar 5 . Kesulitan yang dialami peserta adalah pada fase menjahit dan membuat kreasi pola. Tim pengabdian akan melakukan monitoring dan pendampingan secara mendalam khususnya untuk proses menjaHdit dan kreasi pola.

\section{Prosentase Pemahaman Peserta penyuluhan}

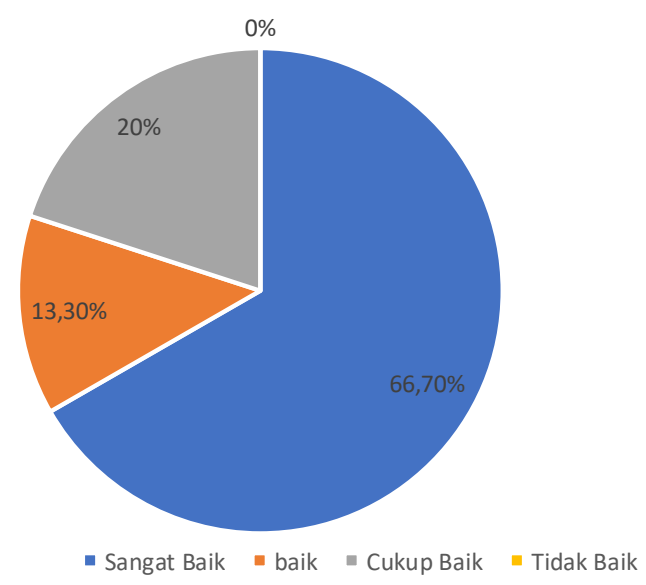

Gambar 5. Presentase pemahaman peserta penyuluhan

\section{Ketercapaian Pembuatan Produk Vinyl Houseware}

Secara umum tahapan ini dilakukan dengan lancar. Peserta secara antusias mengikuti dan mampu mengkreasikan perpaduan model dan warna untuk hiasan houseware yang digunakan. Produk yang dihasilkan berupa tempat sampah, tempat tissue, toples, kreasi kaleng biskuit, nampan dan pot bunga. Produk yang hasilkan sudah memenuhi kriteria kelayakan produk yang mencakup pemilihan warna, desain dan kerapian jahitan dan proses finishing. Terdapat 7 model houseware yang mampu dibuat oleh peserta pelatihan seperti pada gambar 6 .

\section{Kesimpulan}

Limbah vinil dapat dimanfaatkan dan dikreasikan untuk meningkatkan nilai jual produk houseware. Pelatihan pembuatan limbah vinil menjadi houseware ini 
sangat relevan dan bermanfaat bagi peningkatan skill kelompok Koperasi Wanita Putri Jati Emas. Secara garis besar dapat disimpulkan bahwa kegiatan pengabdian masyarakat ini telah berhasil melampaui indikator yang telah ditetapkan. Pemahaman peserta mencapai $80 \%$ dari target $75 \%$, dan ada 7 produk baru yang dihasilkan dari indikator 5 produk baru.

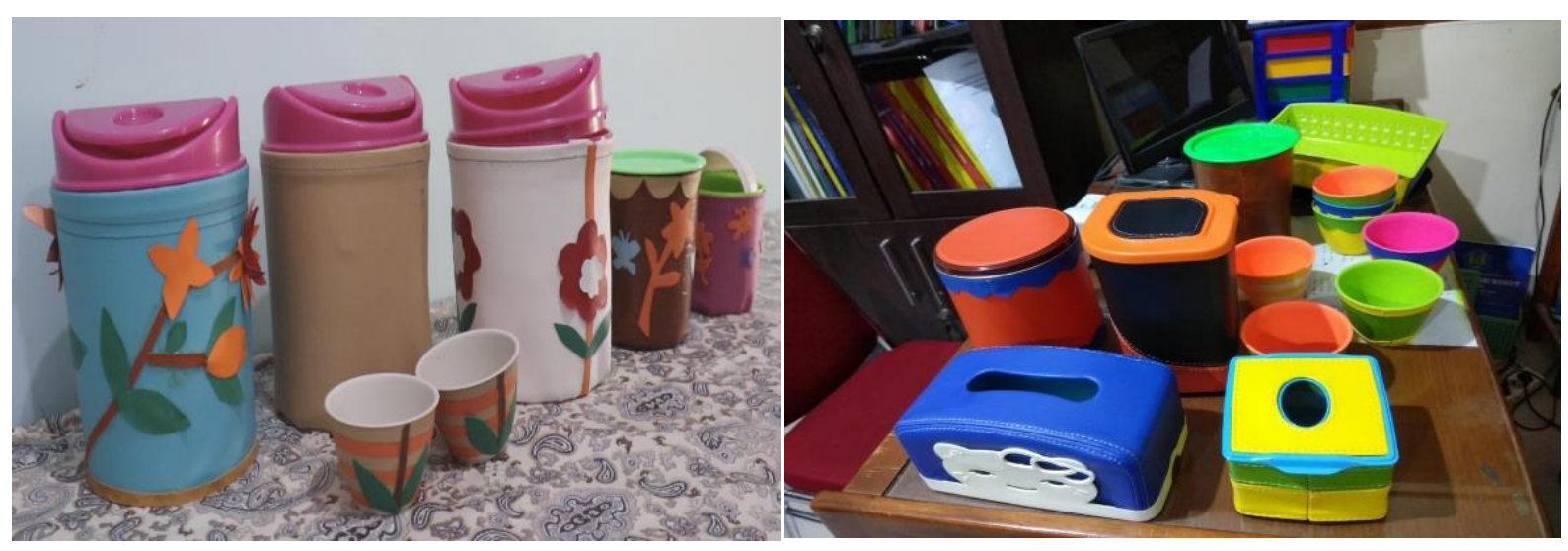

Gambar 6 a,b. Produk vinil houseware

\section{Ucapan Terima Kasih}

Tim pengabdian masyarakat menyampaikan ucapan terimakasih kepada 1) Kemenristekdikti yang telah memberikan bantuan pendanaan program ini melalui Hibah Program Kemitraan Masyarakat tahun 2019. 2) Kelompok Koperasi Wanita Putri Jati Emas sebagai Mitra PKM, 3) Dinas Koperasi dan Usaha Mikro Kabupaten Ngawi yang memberikan dukungan dan arahan, 4) Pemerintah Desa Setono, 4) Wahana Jok dan Interior mobil sebagai penyuplai limbah dan 5) Universitas PGRI Madiun yang memberikan fasilitas pendukung.

\section{Referensi}

Adriansyah, G., Prasnowo, M. A., Rodli, A. F., \& Hidayat, K. (2017). Pengembangan Sentra Industri Tas Dan Koper Tanggulangin Dalam Menghadapi MEA. Jurnal Darussalam: Jurnal Pendidikan, Komunikasi dan Pemikiran Hukum Islam, 9(1), 24-31.

Hasan, M. (2018). Pembinaan Ekonomi Kreatif dalam Perspektif Pendidikan Ekonomi. JEKPEND: Jurnal Ekonomi dan Pendidikan, 1(1), 81-86.

Herlambang, Y. (2015). Peran Kreativitas Generasi Muda Dalam Industri Kreatif Terhadap Kemajuan Bangsa. Jurnal Teknologi Informasi dan Komunikasi (Tematik), 2(1), 61-71.

Indahyani, T. (2010). Sukses Mengembangkan Desain Seni dan Kerajinan Menjahit Aplikasi Berbahan Dasar Limbah Kain (Kain Perca) bagi Industri Rumah Tangga. Humaniora, 1(2), 431-444.

Karno. (2013). Teknologi Pemanfaatan Limbah. IKIP PGRI Madiun Press.

Khairani, S., \& Pratiwi, R. (2018). Peningkatan Omset Penjualan Melalui Diversifikasi Produk dan Strategi Promosi Pada UMKM Kerajinan Souvenir Khas Palembang. CARADDE: Jurnal Pengabdian Kepada Masyarakat, 1(1), 3643.

Pujiati. (2015). Modul Pemanfaatan Limbah Sintetis. IKIP PGRI Madiun Press.

Rochaya, L. (2011). Model Pemberdayaan Perempuan Melalui Pendidikan Keterampilan Kewirausahaan Dengan Bimbingan Dalam Pengembangan Kerajinan Tangan Payette Pada Majelis Ta'lim Perempuan Parung-Bogor. Jurnal Ilmiah Pendidikan Lingkungan dan Pembangunan, 12(2), 31-50. 
Saidah, D. (2017). Pemberdayaan masyarakat disabilitas melalui keterampilan handicraft: tuna rungu wicara di yayasan rumah regis tanjung barat jakarta selatan (Bachelor's thesis, UIN Syarif Hidayatullah Jakarta: Fakultas Ilmu Dakwah dan Ilmu Komunikasi, 2017).

Setyaningrum, A., \& Hartanto, B.W. (2020). Peningkatan Kapasitas Istri Nelayan dalam Pengolahan Hasil Perikanan di Dusun Kuwaru Desa Poncosari Kabupaten Bantul. Jurnal Panrita Abdi, 4(2), 184 - 194.

Suryolaksono, B. (2015). Studi Deskriptif Tentang Program Disperindag Dalam Pemberdayaan Usaha Kecil Menengah Kerajinan Tangan (Handycraft) Di Kelurahan Wonorejo Kecamatan Tegalsari Kota Surabaya. Jurnal Kebijakan dan Manajemen Publik, 3(1)

USAID. (2015). Pengolahan Limbah Berbasis Masyarakat. Tim ESP USAID.

Vinda, K. (2017). Efektivitas Program Pemberdayaan Masyarakat dalam Kelompok Usaha Bersama (Studi Kasus Pada Pemberian Bantuan Mesin Jahit Kelompok Usaha Bersama Bunga Sejahtera Desa Ngampungan Kecamatan Bareng Kabupaten Jombang). Publika, 5(1).

Penulis:

Agita Risma Nurhikmawati, Jurusan Pendidikan Bahasa Inggris, Fakultas Keguruan dan Ilmu Pendidikan Universitas PGRI Madiun, Madiun. E-mail: agitarnurhikmawati@unipma.ac.id Wachidatul Linda Yuhanna, Jurusan Pendidikan Biologi, Fakultas Keguruan dan Ilmu Pendidikan Universitas PGRI Madiun, Madiun. E-mail: linda.yuhanna.wiguno@gmail.com

Bagaimana men-sitasi artikel ini:

Nurhikmawati, A.R., \& Yuhanna, W.L. (2020). Pemberdayaan Kelompok Koperasi Wanita Putri Jati Emas Melalui Pembuatan Houseware dari Limbah Vinil. Jurnal Panrita Abdi, 4(3), 273-280. 